\title{
PRZEKŁAD I ORYGINAŁ POLSKA I FRANCUSKA WERSJA OSIEMNASTOWIECZNEGO DZIEŁA APOLOGETYCZNEGO ${ }^{1 *}$
}

\begin{abstract}
Partyka Joanna, Przeklad i oryginat. Polska i francuska wersja osiemnastowiecznego dzieła apologetycznego (The Translation and the Original: the Polish and the French Version of the Eighteenth-Century Apologetic Work).

The author juxtaposes the little-known dialogue treatise of Jakub Zajączkowski's Rozmowy filozoficzne (Philosophical Conversations, 1780) with its French prototype, Observations philosophiques (1771) by François Xavier de Feller. The works refer to the Pre-Enlightenment and Enlightenment philosophical and theological discussions in which issues in the field of natural science, geology, astronomy, and physics arise. The comparison yields some interesting conclusions.
\end{abstract}

Keywords: apologetic literature; dialogue; the Enlightenment; François Xavier de Feller; Christiaan Huygens; Jakub Zajączkowski; Copernican theory reception; Dialogues of the Dead.

Rozmowy filozoficzne o trzęsieniu ziemi, piorunach etc., o ułożeniu planet podtug Kopernika i o wielości światów to interesujący przykład popularnego w końcu XVII i w XVIII w. gatunku określanego jako dialogi zmarłych. Tekst jest przekładem z języka francuskiego, dokonanym przez bliżej nieznanego benedyktyna Jakuba Zajączkowskiego. Udało się jedynie ustalić, że w roku 1783 nauczał on wymowy w Pułtusku, w 1788 r. był przeorem w klasztorze świętokrzyskim, a w 1793 r. pełnił funkcję prepozyta w Koniemłotach na ziemi sandomierskiej. Na wydane w roku 1780 Rozmowy filozoficzne ${ }^{2}$, liczące dzie-

1* Projekt został sfinansowany ze środków Narodowego Centrum Nauki przyznanych na podstawie decyzji numer 2011/03/B/HS2/05588.

${ }^{2}$ Rozmowy filozoficzne... 2014. Egzemplarze BUW (5.8.14.171/1) oraz BJ (44287 I) poprzedzone są krótką dedykacją oraz łacińskim tekstem Bonifacego Zgliczyńskiego, Conclusiones ex physica generali. Na końcu znajduje się następująca informacja: „Defendentur publicè in Monasterio Lubinensi a R. P. Bonifacio Zgliczynski, Philosopho Consummato, in assistentia A. R. P. Jacobi Zajączkowski Ord: S. Benedicti. 1780. Mediis 7bris”. O samym Zajączkowskim niewiele wiadomo. Conclusiones to zestaw dwunastu praw fizyki; tekst ten został najwyraźniej dołączony później, ponieważ ma własną numerację (jedna karta). W egzemplarzu Biblioteki Uniwersytetu Wrocławskiego sygn. XVIII-7046-II tego dodatku nie ma. 
więćdziesiąt sześć stron, składają się cztery dialogi: Rozmowa I. Między Filozofem i Teologiem o trzęsieniu ziemi, piorunach i tym podobnych, Rozmowa II. Między Galileuszem i kardynatem Bellarminem, iż systema Kopernika jako hypothesis tylko być ma trzymane, Rozmowa III. Między X. Kircherem i Hugeniuszem $^{3}$ o wielości światów oraz Rozmowa IV. Między temiż samemi w tejże materii. Tekstowi Zajączkowskiego poświęciła parę stron Zofia Sinko w książce Oświeceni wśród Pól Elizejskich ${ }^{4}$, badaczka nie wskazała jednak, jakie dzieło było podstawą przekładu. Sinko tak charakteryzuje zawartość Rozmów:

\begin{abstract}
Autor, dobrze zorientowany, jak wynika z licznie przez niego cytowanych dzieł i obfitych przypisów, w piśmiennictwie naukowym XVII i XVIII w. dotyczącym astronomii, fizyki i ogólniejszych zagadnień przyrodoznawstwa, podejmuje z punktu widzenia nauki Kościoła polemikę z niektórymi ze stwierdzeń lub hipotez wspomnianych nauk. Dialogi stanowią więc zapis uczonej dysputy, w której rozmówcy wypowiadają się szeroko i dokładnie na tematy naukowe, zmieniając często wypowiedzi dialogowe w przydługie wykłady swoich poglądów ${ }^{5}$.
\end{abstract}

Treść Rozmów ma charakter apologetyczno-popularyzatorski. Nawiązuje do przedoświeceniowych i oświeceniowych dyskusji filozoficzno-teologicznych, w których pojawiają się - szeroko omawiane także w siedemnastowiecznych i późniejszych encyklopediach - kwestie z zakresu przyrodoznawstwa, geologii, astronomii i fizyki, ale także podejmowane w ówczesnych traktatach i rozprawach naukowych. Głównym celem dialogu oświeceniowego było dotarcie do prawdy, uczestnicy debaty starają się zatem przekonać przeciwników do swoich racji, przy czym mają one wymiar moralno-światopoglądowy. Teologiczne widzenie wszechświata prezentują Teolog, kard. Roberto Bellarmino, oraz przedstawiciel siedemnastowiecznego encyklopedyzmu, jezuita Athanasius Kircher. Zaniepokojeni są nowinkami propagowanymi przez „bezbożnych” filozofów, chorych na „filozofską mózgu chorobę”, jak to ujmuje kard. Bellarmino ${ }^{6}$. Ich adwersarze - Filozof, Galileusz i Christiaan Huygens - są wyrazicielami naukowego światopoglądu, niezupełnie zgodnego z naukami Kościoła. Rozważane są tu kontrowersje wokół przyczyn trzęsienia ziemi i innych zjawisk przyrodniczych, wokół teorii kopernikańskiej i hipotezy o „wielości światów”. Debata, prowadzona w sposób rzeczowy, wyważony i spokojny, pozwoliła na dogłębne zaprezentowanie ówczesnej wiedzy z zakresu astronomii, fizyki i przyrodoznawstwa. Polemiści obficie posługują się cytatami z Pisma św., Ojców Kościoła, ale też z szesnasto-, siedemnasto- i osiemnastowiecznych traktatów naukowych, głównie francuskich, a także włoskich i niemieckich.

\footnotetext{
${ }^{3}$ Spolszczone nazwisko Christiaana Huygensa.

${ }^{4}$ Sinko 1976: 143-146.

${ }^{5}$ Sinko 1976: 143 .

${ }^{6}$ Rozmowy filozoficzne...: 2014: 34.
} 
Udało się ustalić ${ }^{7}$, że książka jest przekładem wybranych fragmentów znacznie obszerniejszego, liczącego 180 stron francuskiego dzieła zatytułowanego Observations philosophiques sur les systêmes de Newton, de Copernic, de la pluralité des Mondes, etc. etc. précédées d'un dissertation théologique sur les tremblements de terre, les orages, etc. Ouvrage utile à ceux qui veulent se précautionner contre le ton de la Philosophie moderne, J.F. Bassompierre: Liège 1771. Jego autorem jest François Xavier de Feller (1735-1802), jezuita urodzony w Brukseli, pisarz, profesor literatury, polemista religijny, zwalczający filozofów-encyklopedystów. Feller po kasacie zakonu jezuitów poświęcił się pisaniu i podróżowaniu, był m.in. $\mathrm{w}$ Polsce ${ }^{8}$. Zapisał się w historii przede wszystkim jako autor wielotomowego słownika biograficznego Dictionnaire historique (Augsbourg 1781-1784), a także Catéchisme philosophique (Liège $1773)^{9}$. Jonathan Israel, współczesny brytyjski historyk, tak pisze o autorze $O b$ servations philosophiques:

Jeden z najbardziej znanych anty-filozofów, luksemburski ex-jezuita François-Xavier de Feller (1735-1802) postrzegał „imperium filozofizmu” jako światowy spisek. Filozofizm, wyjaśniał, to potężny konstrukt myślowy, zainicjowany w latach czterdziestych XVIII w. przez grupę rewelacyjnych pisarzy, którym udało się zafascynować szerokie kręgi dowcipem i ironią, wprowadzając całkowicie nowy język i nowy sposób myślenia i sprawiając, że przez przewrotne i niejasne użycie terminów - ich zgubne pomysły wydały się wielu ludziom „wzniosłe”. „Spisek” rozpoczął się wraz z Diderotem, który zamienił Encyklopedię w aparat dywersji i bezbożności ${ }^{10}$.

${ }^{7} \mathrm{~W}$ ustaleniach tych pomogła mi Izabela Wiencek z Gabinetu Starych Druków BUW, za co w tym miejscu serdecznie jej dziękuję. Zależność dzieła Zajączkowskiego od francuskiego oryginału zasygnalizowała już Barbara Bieńkowska (1971: 227).

${ }^{8}$ Feller opisał wrażenia z tych podróży w Itinéraire, ou voyages de Mr. l'Abbé de Feller en diverses parties de l'Europe: en Hongrie, en Transylvanie, en Esclavonie, en Bohême, en Pologne, en Italie, en Suisse, en Allemagne, en France, en Hollande, aux Pays-Bas, au Pays de Liège etc. Dziennik podróży został wydany już po śmierci autora w Paryżu w 1820 roku. Feller wielokrotnie przekraczał granice Polski. Rozwodził się z zachwytem nad Krakowem i jego kościołami. Nie miał zbyt dobrego mniemania o Polakach. Był w Polsce dwa lata i opuścił ją w październiku $1766 \mathrm{r}$.

${ }^{9}$ Estreicher notuje Katechizm Filozoficzny czyli Zbiór dowodów stużących na obronę Wiary Chrześciańskiey przeciwko nieprzyjaciołom jey. Dzieło pożyteczne dla tych, którzy chcq uniknać zarazy od niedowiarków teraźnieyszych, a mianowicie dla Duchownych, którym z obowiazku należy drogi skład Wiary S. w catości dochować. W języku francuzkim napisane przez X. Flexier de Reval [pseudonim Fellera, anagram] thumaczone przez X. Th. Waluszewicza [Tomasz Dominik (1747-1800)] Filoz. Dokt. Plebana Poszwitińskiego, t. 1-2, W drukarni królewskiej, Wilno 1784.

${ }^{10}$,Among the best-known antiphilosophers, the ex-Jesuit Luxembourgois, François-Xavier de Feller (1735-1802), dubbed the world conspiracy, as he saw it, 'l'empire du philosophisme'. Philosophisme, he explained, was a mighty construct begun in the 1740 s by a group of extraordinary writers who managed to impress sections of all classes with their wit and sarcasm, devising a whole new language and way of thinking, and by cunning dexterity and obscure use of terms made their ruinous ideas seem 'sublime' to many. The 'conspiracy' commenced with Diderot, who turned the Encyclopédie into an engine of subversion and impiety"; Israel 2014: 17. 
W porównaniu z polskim przekładem, francuski oryginał jest zdecydowanie bogatszy pod względem przypisów erudycyjnych czy liczby wskazanych w odniesieniach nazwisk osiemnastowiecznych uczonych (fizyków, astronomów); polski autor ogranicza się właściwie do przypisów bibliograficznych. W oryginale na marginesie pojawiają się odniesienia do miejsc biblijnych i do współczesnych autorowi dzieł, podczas gdy w polskiej wersji marginesy są puste. Poza tym przekład wiernie oddaje treść pierwowzoru, nawet naśladuje grafikę. Najważniejszą jednak różnicą pomiędzy oryginałem a przekładem jest to, że polski autor znacznie skrócił pierwowzór, ograniczając się do czterech dialogów, podczas gdy francuska wersja składa się z sześciu rozmów, przy czym ta opuszczona część jest wyjątkowo obszerna, zajmuje ponad siedemdziesiąt stron. W rezultacie polski czytelnik otrzymuje dzieło o połowę krótsze. Nasuwa się pytanie, dlaczego Zajączkowski podjął taką decyzję. Pytanie to będzie mi towarzyszyć w trakcie analizowania poszczególnych dialogów właśnie pod kątem różnic pomiędzy przekładem, a jego podstawą.

Zgodnie z zapowiedzią w tytule francuskie dzieło rozpoczyna się rozmową Filozofa z Teologiem. Dialog ten nie nosi liczby porządkowej, podczas gdy w polskiej wersji jest to Rozmowa I. Między Filozofem i Teologiem o trzęsieniu ziemi, piorunach, $i$ tym podobnych. Przyświeca jej znamienne motto z Wergiliusza „Non haec sine numine divum eveniunt” („Nie bez woli bogów to pochodzi”, Verg. Aen. II, 777-778). Dyskutanci spierają się o to, czy „trzęsienia ziemi, pioruny i tym podobne" można interpretować w kategorii kary za grzechy i boskiego gniewu. Była to kwestia ważna z punktu widzenia teologicznego, a nabrała szczególnego znaczenia po trzęsieniu ziemi w Lizbonie w roku 1755. Kataklizm, jaki nawiedził stolicę Portugalii w niedzielę 1 listopada, był potrójny: podziemne wstrząsy przyczyniły się do rozległych pożarów, a następnie pojawiła się potężna fala tsunami. Ziemia, ogień i woda sprzysięgły się, by odebrać życie tysiącom mieszkańców. Wiele osób zginęło w kościołach, gdzie właśnie odprawiano msze. Pojawiło się natychmiast pytanie, czym sobie na to zasłużyli. „Dlaczego Lizbona?” - pytali nie tylko pozostali przy życiu lizbończycy, ale i cała Europa. Pytanie takie zadał także Wolter, przyczyniając się do podgrzania dysput $^{11}$. To trzęsienie ziemi staje się argumentem i zarazem kontrargumentem w dialogu Fellera. Filozof wielokrotnie powołuje się na Woltera. Zwraca się do Teologa:

To ty pewnie rozumiesz, że klęski publiczne są zawsze skutkiem grzechów naszych i że jeżeli Lizbona zapadła, to szczególnie dla zbrodni swoich? Lecz wytknął to jeden wielki człowiek, mieniąc, iż Lizbona zginęła, a w Paryżu dobrze jeszcze tańczą. Paryż podług wszelkiego pozoru bardziej grzeszny aniżeli Lizbona, powinien by podług twojego systema zginąć pierwej $^{12}$.

\footnotetext{
${ }^{11}$ Voltaire 2014.

${ }^{12}$ Rozmowy filozoficzne... 2014: 15.
} 
Filozof prezentuje naukowy pogląd na zjawiska przyrody, jego przeciwnik rzeczowo broni pozycji teologii, przy czym obaj skłonni są do pewnych ustępstw. Teolog nie odrzuca w całości, w owych czasach zbadanych już empirycznie, zjawisk natury, a Filozof, człowiek religijny, skłonny jest spokojnie rozważać argumenty Teologa. Dialog rozpoczyna Filozof, który uważa, że poznanie przyczyn rzeczy uwalnia ludzi od bojaźni i jest źródłem szczęścia. Pojawia się w tym miejscu odwołanie do Georgik Wergiliusza: „Felix qui potuit rerum cognoscere causas" ${ }^{13}$ (,Szczęsny zaiste ten, kto zdołał przyczyny wszechrzeczy poznać”). Filozof jest zdania, że nie należy „przypisywać mocy wyższej i niewidzialnej najprostszych przyrodzenia działań" ${ }^{14}$. Teolog nie zgadza się z tym racjonalistycznym twierdzeniem, wysuwając argument, że lęk przed żywiołami i zarazą jest czymś pożądanym, a przyczyny wszystkich zjawisk nie są oczywiste ${ }^{15}$. Teolog przyznaje, że ,trzęsienia ziemi, pioruny, wezbrania wód, i tym podobne rzeczy były skutkiem przyczyn fizycznych”, ale dodaje, że „przyrodzenie posłuszne zawsze było Bogu, i skłaniało się na rozkazy jego"16. Przewrotnie powołuje się na „pogańskiego wierszopisa”, czyli Owidiusza ${ }^{17}$, który uważa, że „tak pioruny, jako też mgły i chmury z zrządzenia Boskiego powstają"18. Feller cytuje w przypisie odpowiedni fragment Metamorfoz, podczas gdy w polskiej wersji brak tego cytatu. Rozmowa przebiega z zachowaniem wszelkich cech poważnej debaty polemicznej. Można w niej prześledzić z rozwagą zastosowane zabiegi retoryczne. Teolog częściej powołuje się na autorytety, głównie jest to Stary i Nowy Testament oraz pisma św. Augustyna, Laktancjusza, Waleriusza Maksymusa, Tertuliana, Owidiusza. Cytuje także lub wskazuje na Pliniusza Starszego (Historia naturalna), Francisa Bacona oraz Jeana Jacquesa Rousseau. Obaj dyskutujący wykorzystują w argumentacji bądź kontrargumentacji Wergiliusza, Woltera i Kirchera. Rozmowa kończy się zwycięstwem Teologa. Filozof zabiera głos jako ostatni, przyznając rację adwersarzowi: „Podźwignąłeś mię z moich uprzedzeń, a wykręty filozofskie nie tak mię łatwo usidlić będą mogły potym"19.

Zajączkowski przekładając tę Rozmowę... opuścił bibliograficzne marginalia (niektóre wciągnął do tekstu lub do przypisów), znacznie skrócił lub pominął wiele odsyłaczy o charakterze erudycyjnym. Znamienne jest, że nie przywołał za Fellerem popularnego w XVIII w. wielotomowego dzieła, reprezentującego

${ }^{13}$ Rozmowy filozoficzne... 2014: 2. Verg. Georg. II, 490.

${ }^{14}$ Rozmowy filozoficzne... 2014: 3.

${ }^{15} \mathrm{Tu}$ w oryginale znajduje się przypis, w którym Feller, bez podania dokładnego miejsca, cytuje fragment jednego z listów poetyckich Woltera, odnoszący się do Kartezjusza: „Epitre XXXIV. A M. De Formont en lui renvoyant les ouvres de Descartes et de Mallebranche" (de Feller 1771: 3).

${ }^{16}$ Rozmowy filozoficzne... 2014: 6.

${ }^{17} \mathrm{Za}$ wydaniem: Ovid. Met. I, 51-52.

${ }^{18}$ Rozmowy filozoficzne... 2014: 7.

${ }^{19}$ Rozmowy filozoficzne... 2014: 29. 
teologię postępową Le Spectacle de la nature ou entretiens sur le particularités de l'histoire naturelle Noël-Antoine'a Pluche' ${ }^{20}$. Autor oryginału wielokrotnie sięga do tego dzieła, cytując obszerne jego fragmenty w przypisach ${ }^{21}$. Polski tłumacz pominął także w jednym z odsyłaczy dane bibliograficzne wskazujące na podręcznik kaznodziejski Antoine'a Alberta Dictionnaire portatif des prédicateurs françois (Lyon 1757). Nie pojawia się także w polskiej wersji w argumentacji Filozofa odsyłacz do Kirchera i jego niezwykle popularnej encyklopedii Mundus subterraneus (1664-1678) ${ }^{22}$. Feller precyzuje, że chodzi mu o rozdział XII z księgi drugiej. Stąd zapewne czerpał nie tylko informacje o budowie ziemi i jej ruchach, ale też cytaty z autorów starożytnych i wczesnochrześcijańskich, do których odnosi się w przypisach ${ }^{23}$.

Kolejne dwie części oryginału (Entretien Premier: Sur la nature de Démonstrations Newtoniennes ${ }^{24}$ oraz Entretien Second: Sur le mouvement des Astres et le genie des Newtoniens ${ }^{25}$ ) zostały opuszczone w całości przez polskiego thumacza. Bohaterami obu dialogów są Newton i Huet. Zajączkowski pomija zupełnie naukę Newtona (1642-1727), która zajmuje sporo miejsca w Rozmowach francuskich. Pierre Daniel Huet (1630-1721), duchowny katolicki (biskup) pochodzący z rodziny o tradycjach protestanckich, był pisarzem, erudytą, wydawcą, członkiem Akademii Francuskiej i zażartym przeciwnikiem myśli Kartezjusza. Isaaka Newtona, sprawcę rewolucji naukowej, posądzano z kolei o podważanie francuskiej nauki i oficjalnie obowiązującego i akceptowanego przez Kościół światopoglądu ${ }^{26}$. Oba dialogi zaopatrzone są w obszerne przypisy erudycyjne oraz marginalia. Feller wkłada w usta dyskutujących odniesienia do wielu osiemnastowiecznych francuskich i włoskich uczonych, filozofów i pisarzy, którzy brali udział w ówczesnych debatach filozoficznych. W tekście wspomina się m.in. antykwarystę i kolekcjonera starożytności hrabiego AnneClaude'a de Caylusa (1692-1765), Giuseppe Boscovicha (1711-1787), Louisa Bertranda Castela (1688-1757), jezuitę, matematyka, zwolennika Kartezjusza i zaciekłego przeciwnika Newtona, ale też postacie wcześniej żyjące: Giovanniego Battistę Riccioliego (1598-1671), włoskiego jezuitę-astronoma, JacquesBénigne'go Bossueta (1627-1704), biskupa i teologa, czy poetę oraz pedagoga Françoisa Fénelona (1651-1715) toczącego spory z Bossuetem. Wspomina się także Pierre'a Bayle'a (1647-1706). Huet wielokrotnie odwołuje się do wymierzonego w filozofię epikurejską poematu Anti-Lucretius, sive de Deo et natura (Lipsiae 1748), którego autorem był zwolennik Kartezjusza, członek Akademii

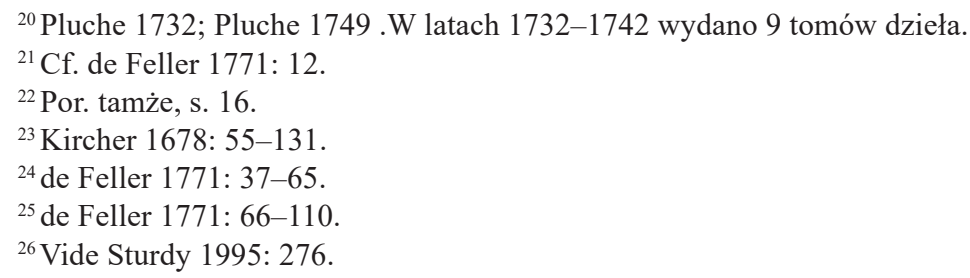


Francuskiej i ambasador francuski w Polsce, kard. Melchior Polignac (16611742). Feller cytuje obszerny fragment tego dzieła ${ }^{27}$.

Trzecią rozmowę (drugą w wersji polskiej) prowadzą kard. Roberto Bellarmino (1542-1621) ${ }^{28}$ i Galileusz (1564-1642), prekursor nowożytnej mechaniki i astrofizyki. Bellarmino znał i cenił Galileusza jako uczonego, pełniąc funkcję inkwizytora nie mógł jednak zgodzić się z jego kopernikańskimi poglądami. Polski autor wiernie przełożył ten dialog, choć już w tytule dostrzegamy drobną, choć znamienną różnicę: w polskim dziełku Bellarmino rozmawia z Galileuszem o tym, „iż systema Kopernika jako hypothesis tylko być ma trzymane”, podczas gdy Feller poprzestaje na wyjaśnieniu, że włoski teolog rozmawia z Galileuszem o „systemie kopernikańskim”. Polski tytuł zdaje się dopowiadać, co będzie zawierał dialog, sprawa ta została zresztą wyłożona w pierwszym przypisie, wiernie przetłumaczonym z oryginału:

Galileusz dał był słowo kardynałowi Bellarminowi, iż nie miał uczyć zdania Kopernika, tylko jako hypothesim, wszakże ludzie przywiązani do jakiego systema zazwyczaj nie dotrzymują podobnej umowy ${ }^{29}$.

Bellarmino zarzuca zatem Galileuszowi niedotrzymanie obietnicy. Zajączkowski pomija ważne informacje zawarte $\mathrm{w}$ przypisach, $\mathrm{np}$. odniesienie do Antoine'a Augustina Calmeta, benedyktyńskiego mnicha, autora komentarzy do Pisma św. Commentaire littéral sur tous les livres de l'Ancien et du Nouveau Testaments (1707-1716). Czasem jednak Zajączkowski poszerza informację bibliograficzną. Tam, gdzie w oryginale pojawia się enigmatyczne określenie ,jedna z naszych dusz", tłumacz wskazał dzieło chorwackiego, a wówczas ,włoskiego" jezuity, uczonego fizyka, filozofa i astronoma Rudera Josipa Boskovicha De lumine $(1748 \text { r. })^{30}$. Warto podkreślić, że dokładnie wskazane zostało miejsce wyrażonego przez uczonego sądu. Zajączkowski precyzuje również, że: „Filozof pewny, który tu niezadługo ma przybyć i który niekoniecznie wielkim jest przyjacielem Pisma ś." to Wolter ${ }^{31}$. W oryginale odniesienie do tego autora znajduje się na marginesie i ma formę skróconą: „Volt. Mél. De Litt. et de l'Hist.””22. W innym miejscu Zajączkowski rozszyfrowuje, że ,jedną z naszych dusz” jest Noël-Antoine Pluche. Jego poglądy o „punktualności rachunków”, czyli dokładności tablic astronomicznych, znajdują się, jak podaje benedyktyński tłumacz,

${ }^{27}$ de Feller 1771: 45-46.

${ }^{28}$ Brodricki 1961; Urbański 2016: 181-221.

${ }^{29}$ Rozmowy filozoficzne..., 2014: 31.

${ }^{30}$ Rozmowy filozoficzne..., 2014: 40; w wersji włoskiej: Ruggiero Giuseppe Boscovich (1711-1787).

${ }^{31}$ Rozmowy filozoficzne..., 2014: 34.

${ }^{32}$ de Feller 1771: 114; pełny tytuł to: Mélanges de littérature, d'histoire et de philosophie. Nie wiadomo, o które wydanie chodzi. 
w tomie IV dzieła ${ }^{33}$. Interesująca wskazówka na marginesie tekstu oryginalnego odnosząca się, bez podania autora, do dzieła Copernicus triumphans sive de parallaxi orbis annui tractatus epistolaris z 1727 r. duńskiego astronoma Pedera Horrebowa, została pominięta przez polskiego tłumacza ${ }^{34}$. Nieliczne łacińskie cytaty z oryginału Zajączkowski przekłada na polski. Końcowe strony dialogu Galileusza z Bellarminem, przede wszystkim rozbudowana argumentacja kardynała, $\mathrm{w}$ oryginale są zaopatrzone $\mathrm{w}$ obszerne komentarze erudycyjne, które zostały pominięte przez Zajączkowskiego ${ }^{35}$.

Dwie ostatnie dysputy, podnoszące kwestię „wielości światów”, prowadzą Athanasius Kircher (1602-1680) ${ }^{36}$, jezuicki encyklopedysta, i Christiaan Huygens (1629-1695), matematyk i astronom, członek londyńskiego Royal Society. Jako jeden z pierwszych uczonych brał pod uwagę istnienie życia pozaziemskiego. Teorię tę wyłożył w dziele Cosmotheoros ukończonym w roku 1695 i wydanym, pośmiertnie, trzy lata później. Kircherowi ma za złe, że „nie dojrzał wielości światów i mieszkańców na planetach"37. Jezuita odpowiada tak:

Postrzec to można w moim Podróżniku ekstatycznym, iż ta myśl nie raz mi przychodziła do głowy, lecz tylem w niej znajdował trudności, iż odważyć się nie mogłem, abym na nią miał przystać c $^{38}$.

Podobnie jak w poprzednim dialogu, polski tłumacz pominął obszerne przypisy zawierające informacje o kometach, wskazówki bibliograficzne, erudycyjne dopowiedzenia, a także charakterystyczne marginalia przy odsyłaczach. Czasem jednak dodaje coś od siebie. Na przykład przełożone wiernie za oryginałem zdanie: „Jako pokazał niedawnymi czasy wielki jeden filozof...”, w przypisie uzupełnia odnośnikiem do Anti-Lucretiusa ${ }^{39}$ i odpowiednim cytatem: „Ut magnam oceanus partem telluris inundet...", którego nie ma w oryginale ${ }^{40}$. W tej części dzieła Hugeniusz przywołuje irlandzkiego filozofa-empirystę George'a Berkeleya (1685-1753) i jego koncepcję, w myśl której, jeśli coś nie jest obserwowalne, pozostaje jedynie w sferze wyobrażeń, czyli nie istnieje (esse równoznaczne jest z percipi). Sofizmat anglikańskiego duchownego został tu wykorzystany jako przykład negatywny, mówi bowiem Hugeniusz, polemizując z Kircherem: „Jednak my sprawiedliwie domyślać się możemy, że to wszystko znajduje się na planetach, co u nas na ziemi”"41. W przypisie pojawia się informacja o debacie

\footnotetext{
${ }^{33}$ Rozmowy filozoficzne... 2014: 41.

${ }^{34}$ de Feller 1771: 133.

${ }^{35}$ de Feller 1771: 130-139.

${ }^{36}$ Vide Godwin 2004; Targosz 1968.

${ }^{37}$ Rozmowy filozoficzne... 2014: 64.

${ }^{38}$ Rozmowy filozoficzne... 2014: 64.

${ }^{39} \mathrm{~W}$ polskiej wersji w tytule tego dzieła wystąpił błąd: jest Anti-Lucanus.

${ }^{40}$ Polignac 1748: 164; Rozmowy filozoficzne... 2014: 69-70.

${ }^{41}$ Rozmowy filozoficzne... 2014: 70.
} 
prowadzonej w związku z immaterializmem Berkeleya przez jego przeciwników ${ }^{42}$ - Woltera i Nicolasa Bergiera (1717-1790). Zajączkowski opuścił jednak zamieszczoną przez Fellera informację bibliograficzną odnoszącą się do dzieła Bergiera - Apologie de la religion chrétienne (Paris 1770). Podobnie uczynił z przypisem na marginesie, wskazującym źródło twierdzeń Hugeniusza, mianowicie dzieło Boscovicha De lunae atmosphaera dissertatio (Roma 1753). Znamienne jest, że kolejne strony tego dialogu, aż do końca, pozbawione są obfitych w oryginale - przypisów ${ }^{43}$. Feller powołuje się w nich na sądy Keplera, Cassiniego, Galileusza, Newtona i innych uczonych nowożytnych i antycznych na temat odległości Księżyca i planet od Ziemi, kształtu i ruchu komet, wspomina też francuskiego teologa jezuickiego Denisa Pétau (1583-1652), Giovanniego Battistę Riccioliego, urodzonego we Wrocławiu niemieckiego filozofa Christiana Wolffa (1679-1754) oraz Jana Heweliusza (1611-1687). Dialog kończy się pytaniem skierowanym do Kirchera: „ponieważ na żadnym okręgu niebieskim zezwolić nie chcesz na mieszkańców, powiedzże mi przynajmniej, jaki był cel Najwyższego Rządcy w ich stworzeniu?"44.

Kolejna, ostatnia i najkrótsza rozmowa poświęcona jest na logiczne i teologiczne rozważanie postawionej wyżej kwestii. W oryginale wskazane są miejsca w dziełach adwersarzy potwierdzające ich zdanie, a na marginesach pojawiają się cytaty z Biblii (Księga Psalmów, Księga Przysłów, Księga Rodzaju, Apokalipsa św. Jana), odwołania do listów św. Hieronima i Księgi Izajasza. Polski thumacz z nich rezygnuje. Feller najwyraźniej stawia się w sytuacji dyskutanta zabiera głos w przypisach, zajmujących czasem prawie całą stronicę ${ }^{45}$, podczas gdy polski autor nie zamierza (nie śmie?) tego robić. Interesujące jest, że Feller, a także Zajączkowski nie znali prawdopodobnie nazwiska autora dzieła, o którym wspominają, poprzestając na tytule. Chodzi tu a rozprawę La seule religion veritable: démontrée contre les athées, les déistes, et tous les sectaires (Paris 1744). Feller odnosi się do konkretnej strony tego traktatu, myląc jednak datę wydania, Zajączkowski zaś w ogóle takiej informacji nie zamieszcza. Autorem dzieła był jezuita Jean (Jacques) Lefebvre ${ }^{46}$.

W tym dialogu ostatnie zdanie ma Kircher. Kończy spór twierdzeniem o jedności świata. Powołuje się przy tym na fragment dzieła Fortunata z Brixii Philosophia mentis methodice tractata atque ad usus academicos accomodata secundis curis P. F. Fortunati a Brixia: „Zawsze tak trzymam za pewne i trzymać będę, iż Bóg Stwórca wszechrzeczy jedną tylko stworzył ziemię, na której się ludzie znajdują"

\footnotetext{
${ }^{42}$ Cf. Charles, Brykman 2003: 225-229.

${ }^{43}$ Rozmowy filozoficzne... 2014: 72-82.

${ }^{44}$ Rozmowy filozoficzne... 2014: 81.

${ }^{45} \mathrm{Cf}$. de Feller 1771: 176.

${ }^{46}$ Vide de Backer, de Backer: 1853, 297-298.

${ }^{47}$ Rozmowy filozoficzne... 2014: 96.
} 
Zgodnie z zapowiedzią zastanówmy się obecnie nad wskazanymi różnicami pomiędzy przekładem a oryginałem analizowanego tu dzieła. Zofia Sinko zwraca uwagę, że: „Dialogi zmarłych, podobnie jak oświeceniowe periodyki, słowniki oraz kompendia czy różnorodne mowy i rozprawki, służyły również celom popularyzatorskim"48. Taki cel przyświecał także Jakubowi Zajączkowskiemu. Tłumacz Observations philosophiques... Fellera nie był erudytą, filozofem ani uczonym astronomem. Był natomiast pedagogiem i oddanym nauce Kościoła duchownym. Można sądzić, że wszelkie opuszczenia, skróty, a w rezultacie pewne uproszczenia $\mathrm{w}$ stosunku do tekstu oryginalnego zmierzały do tego, by polski czytelnik otrzymał prostszy i dobitniejszy przekaz. Taki, który bez zbędnych komplikacji, mnogości nazwisk i faktów trafiłby w sedno, czyli bronił tradycyjnego światopoglądu, nie wprowadzając niepotrzebnego niepokoju na etapie zdobywania podstawowej wiedzy na średnim poziomie. Niepokój taki w środowisku filozofów, teologów, astronomów i matematyków trwał co najmniej dwa wieki.

Kontrowersje wokół teorii kopernikańskiej i związane z nią rozterki uczonych widoczne są już we wcześniejszych dziełach powstałych na obszarze Rzeczypospolitej. Można tu dla przykładu przywołać traktat gdańskiego astronoma, autora podręczników Piotra Krügera (1580-1639) ${ }^{49}$. Podchodził sceptycznie nie tyle do całej teorii heliocentrycznej, ile do wielkości wszechświata i związanej z nią kwestii próżni. W swoim dziele zastanawia się, „w jakim celu BógStwórca miałby pozostawić między systemem planetarnym czy niebem Saturna a firmamentem tak niewiarygodnie pustą, stellis vacuum przestrzeń $[\ldots]^{\prime 50}$. Zbigniew Ogonowski, który opublikował w przekładzie fragmenty książki tego autora, pisze:

Atak na Kopernika przypuszczony tu zostaje ze stanowiska uczonego laickiego, obeznanego dobrze $\mathrm{z}$ najnowszymi osiągnięciami wiedzy astronomicznej. W zakończeniu pisma pojawiają się konkluzje filozoficzne, ale opatrzone znakiem zapytania. Są one świadectwem bezradności wobec nasuwających się wniosków, obalających całkowicie dawny obraz świata i dawny sposób myślenia ${ }^{51}$.

Krüger tak przedstawił swoje wątpliwości:

nie rozumiem, jak może ostać się pitagorejski lub kopernikański system świata przy równoczesnym założeniu, że Słońce ma swoją wielkością przewyższać wszystkie inne gwiazdy. Nie mogę tego pojąć, ale jeżeli ktoś to rozumie, to proszę, by mnie pouczy ${ }^{52}$.

\footnotetext{
${ }^{48}$ Sinko 1976: 23.

${ }^{49}$ Krüger 1631.

${ }^{50}$ Krüger 1979: 175.

${ }^{51}$ Krüger 1979: 168.

${ }^{52}$ Krüger 1631: 175.
} 
Podobne wahanie prawie sto lat później wyraził w Rozprawie filozoficznej o wielości światów ${ }^{53}$ Reinhold Fryderyk Bornmann (1685-1747), który akceptował w pełni, jak się wydaje, heliocentryzm i opartą na nim teorię o wielości światów i wielokrotnie powoływał się na dzieło Huygensa Cosmotheoros. A jednak pisze tak: „Zestawione przez nas w niniejszej rozprawie argumenty zgodne z poglądami innych na tę hipotezę są tylko prawdopodobne, a nie dowodzą niezawodnie" 54 . Wyraźnie widać owe moralne i religijne problemy z zaakceptowaniem nie tyle już nowych teorii, co nowych odkryć naukowych.

O pokolenie starszy od Krügera Wojciech Tylkowski (ok. 1625-1695), jezuita, autor łacińskich i polskich kompendiów encyklopedycznych przeznaczonych dla szerokiego odbiory, powraca do teorii geocentrycznej:

Niektórzy uczą, iż Słońce we śrzodku świata stoi, a Ziemia około niego biega, ale to zdanie jako przeciwne Pismu Bożemu, od Kościoła świętego jest potępione roku $1616^{55}$.

Heliocentryzmu nie przyjmuje także Jan Kowalski (1711-1782), jezuicki filozof i teolog, zaniepokojony niebezpieczeństwem, jakie niosą ze sobą nowe prądy myśli europejskiej dla nauki Kościoła. Warto odnotować, że w swojej Rozmowie o filozofii (Lwów 1746) powołuje się m.in. na Hueta i Wolffa ${ }^{56}$, autorów cytowanych w omawianym tu dziele. Roman Darowski zauważa, że:

Kowalski jako pierwszy z jezuitów w Polsce wprowadził język ojczysty do rozważań fillozoficznych. Rozmowa o filozofii pisana w formie dialogu, w której spokojnie i rzeczowo przedstawiał filozofię scholastyczną, [...], bronił jej i krytykował poglądy Kartezjusza, jest jedyną rozprawą przeciw nowej filozofii, szczególnie przeciw kartezjanizmowi, napisaną w języku polskim i to językiem bardzo pięknym ${ }^{57}$.

Wydane ćwierć wieku później Rozmowy filozoficzne... Jakuba Zajączkowskiego, choć nieoryginalne, realizują ten sam zamysł polemiczny, a napisane są ładną, choć niewyrafinowaną polszczyzną.

Antoni Wiśniewski (1718-1784), pijar popierający heliocentryzm oraz teorię wielości światów, w Mowie o korzyściach, jakie sptyna na Polskę z Warszawskiej Akademii Szlachetnych Sztuk i Umiejętności (1753) oraz w Kolędzie Warszawskiej, kalendarzu, który wydawał w latach 1753-1763, zwracał uwage na konieczność popularyzacji myśli europejskiej w Polsce ${ }^{58}$. Przełożone przez Zajączkowskiego dialogi Fellera wpisywały się w działania upowszechniające w Polsce wiedzę wypracowaną w zachodniej Europie. Musiały zarazem budzić

\footnotetext{
${ }^{53}$ Bornmann 1715.

${ }^{54}$ Bornmann 2000: 111.

${ }^{55}$ Tylkowski 1692; cyt. za: Skrzypek 2000: 297.

${ }^{56}$ Vide Kowalski 2000: 36-46.

${ }^{57}$ Kowalski 2000: 38.

${ }^{58}$ Vide Wiśniewski 2000: 328-336.
} 
pewien niepokój, zgodnie z moralistycznym zamiarem autora i charakterem gatunku literackiego.

\section{Zofia Sinko pisze za Rudolfem Hirzelem ${ }^{59}$ :}

Dialog pojawiał się w historii w momentach kryzysu i przemian politycznych, społecznych oraz światopoglądowych. Stawał się on często wyrazicielem duchowego niepokoju epoki, jedną z form, w której manifestowało się zanikanie dawnych oraz powstawanie nowych przekonań i wartości. [...]. Twórca dialogu mógł się usunąć w cień i kazać przemawiać stworzonym przez siebie postaciom, mógł też nie ujawniać całkowicie swoich poglądów i poddać pod osąd czytelnika sprzeczne opinie rozmówców ${ }^{60}$.

Wydaje się, że różnica pomiędzy oryginałem a przekładem polega tu m.in. na tym, że autor eksponował swoją osobę, tłumacz zaś „usunął się w cień”.

\section{BIBLIOGRAFIA}

Teksty źródłowe:

Augustin de Backer, Alois de Backer (red.), Febvre, Jacques le, w: Bibliothèque des écrivains de la Compagnie de Jésus..., vol. I, Liège 1853, 297-298.

R.F. Bornmann, Disputatio philosophica de Pluralitate mundorum, Thorunii 1715.

R.F. Bornmann, Rozprawa filozoficzna o wielości światów, przeł. M. Olszewski, w: 700 lat myśli polskiej. Filozofia i myśl społeczna w latach 1700-1830, vol. I: Okres saski 1700-1763, red. M. Skrzypek, Warszawa 2000.

F.X. de Feller, Observations philosophiques sur les systêmes de Newton, de Copernic, de la pluralité des Mondes, etc. etc. précédées d'un dissertation théologique sur les tremblements de terre, les orages, etc. Ouvrage utile à ceux qui veulent se précautionner contre le ton de la Philosophie moderne, Liège 1771.

A. Kircher, Mundus subterraneus, vol. I, księga 2: Technicus geocosmus, sive de admirando globi terreni opificio, ex Oficina Janssonio-Waesbergiana, Amstelodami 1678.

J. Kowalski, O systemie Kartezjusza, w: 700 lat myśli polskiej. Filozofia i myśl społeczna w latach 1700-1830, vol. I: Okres saski 1700-1763, red. M. Skrzypek, Warszawa 2000, 36-46.

P. Krüger, Cupediae astrosophicae Crügerianae [...], Breslaw 1631.

P. Krüger, Przysmaki gwiezdnej mądrości, przeł. M. Makowski, w: 700 lat myśli polskiej. Filozofia i myśl społeczna XVII wieku, cz. 2, red. Z. Ogonowski, Warszawa 1979.

N.-A. Pluche, Le Spectacle de la nature ou entretiens sur le particularités de l'histoire naturelle, Paris 1764-1770.

M. Polignac, Anti-Lucretius, IV, apud Bernh[ard] Christoph Breitkopf, Lipsiae 1748.

Rozmowy filozoficzne o trzęsieniu ziemi, piorunach etc. o ułożeniu planet podtug Kopernika i o wielości światów, z francuskiego na ojczysty język przełożone przez J.Z.Z.S.B.

[Jakuba Zajączkowskiego Zakonu Świętego Benedykta] za dołożeniem zwierzchności wydrukowane. W Warszawie w drukarni nadwornej J.K. Mci 1780.

F.M. Voltaire, Poème sur le désastre de Lisbonne [1756], Paris 2014.

W. Tylkowski, Uczone rozmowy wszystkę w sobie prawie zawierajace filozofija, Warszawa [1692]. Wergiliusz, Georgiki, w: Bukoliki i Georgiki, przekł. Z. Abramowiczówna, Wrocław 2006.

Wergiliusz, Eneida, przekł. F.K. Dmochowski, Warszawa 1809.

\footnotetext{
${ }^{59}$ Hirzel 1895.

${ }^{60}$ Sinko 1976: 7 .
} 
Opracowania:

Bieńkowska 1971: B. Bieńkowska, Kopernik $i$ heliocentryzm w polskiej kulturze umystowej do końca XVIII w., Wrocław 1971.

Brodrick 1961: J. Brodrick, Robert Bellarmine, Saint and Scholar, Westminster 1961.

Charles, Brykman 2003: S. Charles, G. Brykman, Berkeley au siècle des Lumières: immatérialisme et scepticisme au XVIIIe siècle, Paris 2003.

Findlen 2004: P. Findlen (red.), Athanasius Kircher: the last man who knew everything, New York 2004.

Godwin 1979: J. Godwin, Athanasius Kircher, A Renaissance man and the quest for lost knowledge, London 1979.

Hirzel 1895: R. Hirzel, Der Dialog: Ein literarhistorischer Versuch, vol. I, Leipzig 1895.

Israel 2014: J. Israel, Revolutionary Ideas: An Intellectual History of the French Revolution from The Rights of Man to Robespierre, Princeton 2014.

Skrzypek 2000: M. Skrzypek (red.), 700 lat myśli polskiej. Filozofia i myśl społeczna XVII wieku, cz. 2, Warszawa 2000.

Sinko 1976: Z. Sinko, Oświeceni wśród Pól Elizejskich. Rozmowy zmarlych. Recepcja-twórczość oryginalna, Wrocław 1976.

Sturdy 1995: D.J. Sturdy, Science and Social Status: The Members of the Académie Des Sciences 1666-1750, Woodbridge 1995.

Targosz 1968: K. Targosz, Polscy korespondenci Atanazego Kirchera i ich wktad w jego dzieto naukowe, „Studia i Materiały z Dziejów Nauki Polskiej. Seria A” 12 (1968).

Urbański 2016: P. Urbański, Roberto Bellarmino (1542-1621) i wpływ jego myśli na rozwój kulturowych oraz religijnych idei $w$ Rzeczypospolitej, w: Formowanie kultury katolickiej $w$ dobie potrydenckiej. Powszechność i narodowość katolicyzmu polskiego, J. Dąbkowska-Kujko (red.), Warszawa 2016, 181-221.

Skrzypek 2000: Formowanie się w warszawskim środowisku pijarów. Antoni Wiśniewski w: 700 lat myśli polskiej. Filozofia i myśl społeczna w latach 1700-1830, vol. I, M. Skrzypek (red.), Warszawa 2000, 328-336.

\section{THE TRANSLATION AND THE ORIGINAL: THE POLISH AND THE FRENCH VERSION OF THE EIGHTEENTH-CENTURY APOLOGETIC WORK}

\section{Su m m ary}

Rozmowy filozoficzne by Jakub Zajączkowski are an example of the genre known as the dialogues of the dead, which was popular in the late 17 th century and the $18^{\text {th }}$ century. The text is a translation of selected fragments of a much larger French work by François Xavier de Feller, Observations philosophiques. It served the apologetic purposes as well as to disseminate knowledge. In comparison to the Polish translation, the French original is definitely richer in terms of erudite footnotes. The translator left out the bibliographic marginalia, significantly shortened or omitted many links, and left out important information in the footnotes. Two parts devoted to Newton's science were abandoned entirely. Unlike the Polish translator, the author of the original seems to have taken an active part in the debate between Cardinal Roberto Bellarmino and Galileo, Athanasius Kircher and Christiaan Huygens as well as Newton and Pierre Daniel Huet - his footnotes sometimes occupy almost the entire page. The translator was not a scholar, philosopher or astronomer, but a teacher devoted to the Church. It can be assumed that all omissions, abbreviations and, as a result, oversimplifications in comparison to the original text were aimed at providing the Polish reader with a simpler and clearer message. Whereas the author of the work revealed his identity, and the translator preferred to stay in the shadows. 